\title{
Development of an Enzyme-Linked Immunosorbent Assay for the Organophosphorus Fungicide Tolclofos-methyl
}

\author{
Kỵung Yi Park, Won Chul Park, Yoo Jung Kim, and Yong Tae Lee*

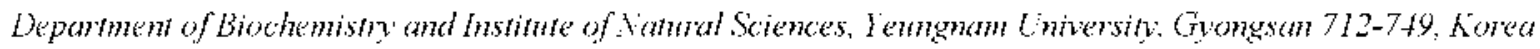 \\ Received lowember +. 2002
}

\begin{abstract}
A simple swnthetic method for haptens of organophowphorus (OP) pexticides with a spaer am (aminowrbosylic acid) atlached at the pesticide thiophosphate group was developed and was applied to the swnthesis of haptens for the OP fungieide tolelolos-methyl. Using the haptens, a selective ensine-linked immunosotent assay (DI.ISA) for tolelotos-methyl was developed. One of the haplens was coupled to BSA to use as an immunogen. Rabbits nere immunized with this conjugate to obtain polyclonal antibodies to tolelotos-methyl. The antisera were sereened against another hapten coupled to ovalbunin (OVA). Tsing the

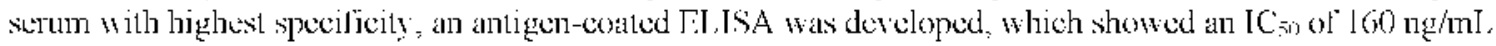
with the detection limit of $20 \mathrm{ng} / \mathrm{mI}$. The antihodies showed negligible eross-reactivity with other $\mathrm{OP}$

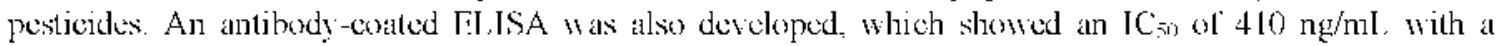
detection limit of $130 \mathrm{ng} / \mathrm{mI}$.
\end{abstract}

Key Words : 'lolclotos-methyl, Fungicide, Enzyme-linked immunosorbent assay, ELISA

\section{Introduction}

Since the 1970s. OP pesticides have replaced the organochlorine insecticides previously used and are now widely used on agricultural crops to control a large varicty of pesis. However. the OP pesticides generally have higher acule toxicity than the chlorinated insecticides. which necessitates comprehensive monitoring programs for them. Tolclofosmethỵl [O,O-dimethỵ] O-(2.6-dichloro-4-mellỵlphenyl) phosphorothioatel is an OP fungicide used for the control of soil-borne discases caused by Rhizoctonia, Corticilm. and Scterotitm on potatocs. sugar bect. vegetables. cercals. bulb nowers. lawn turf. cle., The toxicologically relevant effect after administration of tolclofos-mellyyl is inhibition of phospholipid biosy nthesis. lcading to inlubition of germination of spores and growtl of fungal mycelium.

Current analytical methods imolying gas and liquid cliromatography for the detcction of pesticide residues are sensitive and reliable. ${ }^{2}$ Howerer. they require a high cost and skilled analysts. and inolyc time-consuming sample preparation steps. Thereforc. there is a growing demand for more rapid and cconomical melhods for delennining pesticide residucs. Immunoassays are being demonstrated as a suitable altemative to the iraditional methods that can mect sucl demands. They began recently 10 gain acceptance as a fast. sensitive. and cost-effective tool for cm irommental analy sis. ${ }^{3}$

The development of an immunoassay requires the production of antibodics to the analyte. Since pesticides are sinall molcculcs. pesticide derivatives. namely haptens. must be symlhesized and coupled to carricr proteins to induce antibody production. One type of hapten for OP pesticides is the one with an aminocarboxylic acid bridge at the thiophosphate group. which has been used for the dexelopment of ELISA for several OP pesticides. ${ }^{1-1}=$ Wo have developed a simple melhod for the symthesis of such haptens. which requires far fewer steps and can provide a wider range of lapten struclures. $^{1-6}$ We previously applied this method to the synthesis of scucral OP pesticides including chlorpy rifos." isofenplos. ${ }^{5}$ and cyanophos. ${ }^{6}$ In this study. we further confirmed the general applicability of this method by synthesizing hapiens for the OP fungicide tolclofos-methyl by this method. Then. we raised antibodies against one of licse haptens to develop an antigen-coated and an antibodycoated ELISA for 1olclofos-metlyy. An antibody-coated ELISA for this pesticide las already becn developed by Kawada et al, and was patented. ${ }^{13}$ howerer. an antigencoatcd ELISA. a more popular format. has not yel beer dercloped.

\section{Experimental Section}

Reagents and instruments. Tolclofos-meilyyl was purchased from Chem Service (West Chester. USA). Other OP pesticides were obtained from Dr. Ehrensiorfer (Augsburg. Genmany) ). 2,6-dichloro-4-metlıylplicnol. 4-aminobuty ric acid. 3-(metlyylanino) butyric acid hydrochloride. A-hydroxysuccinimide. 1.3-diçclolexylcarbodimide. and 4-dimetlyylaminopyridine were oblained from Aldrich (Milwaukec. USA), BSA. OVA. horscradish peroxidase (HRP) labeled goat anti-rabbit IgG. Freund's complele and incompletc adjunants. Tween 20. and Sephadex G-25 were purchased from Sigma (S1. Louis. USA). Tetrametlyylbenvidine (TMB) was from Bocluringer Mannheim (Mannheim. Gernany). Analytical (silica gel F254) and preparative TLC plates (silica gel. I $\mathrm{mm}$ ) were obtained from Merck (Dammstadt. Genmany). The dialysis membrane (MW cutoff 12000-14000) was a Spectra/Por product from Specinum Laboratorics (Rancho Domingue\%. USA). Microtiter plates (Maxisorp) were purchased from Nunc (Roskilde. Denmark). ELISA plates were washed witl a Model 1575 ImmunoWash, and 
<smiles>COP(=S)(OC)Oc1c(Cl)cc(C)cc1Cl</smiles>

Tolclofos-methyl

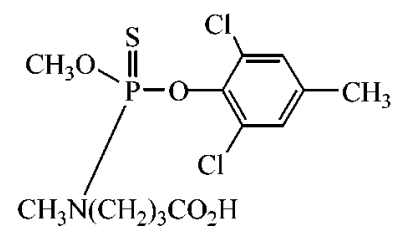

Hapten 1

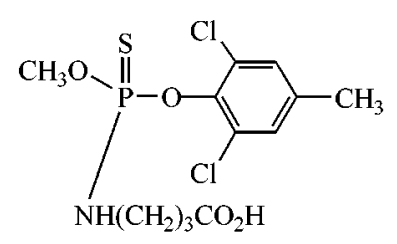

Hapten 2
Figure 1. Structures of the haptens for tolclofos-methyl used for inmunization (1 laplen l), antigen costing (Itaplen 2) and encyme tracer (1 liaplen 2).

well absorbances were read with a Model 550 plate reader. both from Bio-Rad (Hercules. USA). NMR spectra were obtained with a Bnuker (Rheinstetten. Germany) ARX spectrometer $(300 \mathrm{MHz})$. Chemical shift values are given relative to intemal tetrametlyylsilane. Coupling constants are expressed in $\mathrm{Hz}$ and the abbreviations s. d. t. q. qIn. s.. $\mathrm{m}$. and ar represent singlet. doublet. triplet. quartet, quintet. sextet, multiplet. and aromatic. respectively:

Hapten synthesis. The haptens used for immunization and antigen coating are presented in Figure 1. The synthetic route for Hapten 1 is illustrated in Figure 2. The procedure for the synthesis of Hapten 1 was as follows.

1. To a stirred mixture of $1.03 \mathrm{~g}(6.3 \mathrm{mmol})$ of methyl dichlorothiophosphate. ${ }^{1-7}$ finely ground $\mathrm{K}_{2} \mathrm{CO}_{3}$ and $10 \mathrm{~mL}$ acetonitrile was added dropwise $0.93 \mathrm{~g}(5.2 \mathrm{mmol})$ of 2.6diclloro-4-methylphenol dissolved in $3 \mathrm{~mL}$ of acetonitrile. After stirring for $1 \mathrm{~h}$ at room temperature. the mixture was filtered and the solvent was removed under reduced pressure. The residue was subjected to column chromatography (silica gel. $10: 1$ hexane-etlyy acetate) to give $1.23 \mathrm{~g}(67 \%)$ of the product as a colorless oil. 'H NMR ( $\left.\mathrm{CDCl}_{3}\right)$ : $\delta 7.18(2 \mathrm{H}$. s. ar). $4.08\left(3 \mathrm{H} . \mathrm{d} . J=16.5, \mathrm{CH}_{3} \mathrm{OP}\right) .2 .33(3 \mathrm{H} . \mathrm{d}, J=2.3$. $\mathrm{CH}_{3}$-ar).

Hapten 1. To a stirred solution of $0.23 \mathrm{~g}(0.76 \mathrm{mmol})$ of 1 in $1 \mathrm{~mL}$ of methanol cooled in an ice-water bath was added dropwise a solution of $0.16 \mathrm{~g}(2.9 \mathrm{mmol})$ of $\mathrm{KOH}$ and $0.14 \mathrm{~g}$ $(0.91 \mathrm{mmol})$ of 3-(methylamino)butyric acid hydrochloride<smiles>COP(=S)(Cl)Cl</smiles><smiles>Cc1cc(Cl)c(O)c(Cl)c1</smiles><smiles>COP(=S)(Cl)Oc1c(Cl)cc(C)cc1Cl</smiles>
$\mathrm{CH}_{3} \mathrm{NH}\left(\mathrm{CH}_{2}\right)_{3} \mathrm{CO}_{2} \mathrm{H}$ Hapten 1

Figure 2. Svintletic route for $\mathrm{H}_{\mathrm{a}\} \text { te }} \mathrm{l}$. in $0.16 \mathrm{~mL}$ methanol. After stirning for $5 \mathrm{~min}$, the reaction mixture was filtered and the solvent was exaporated. Column chromatography (silica gel. $29: 9: 1 \mathrm{CHCl}_{3}$-etlyl acetateacetic acid) of the residue followed by preparative TLC using the same solvent gave $0.25 \mathrm{~g}(78 \%)$ of a white solid. ${ }^{l} \mathrm{H}$ NMR $\left(\mathrm{CDCl}_{3}\right): \delta 7.13$ (2H. s. ar). 3.85 (3H. d. $J=14.2$. $\mathrm{CH}_{3} \mathrm{OP}$ ). $3.16 \& 3.45\left(2 \mathrm{H} . \mathrm{m}, J=5.1 . \mathrm{NCH}_{2}\right) .2 .90(3 \mathrm{H} . \mathrm{d} . J$ $\left.=11.4 . \mathrm{CH}_{3} \mathrm{~N}\right) \cdot 2 .+3\left(2 \mathrm{H} . \mathrm{t} \times \mathrm{d} . J=7.4 \& 2.6 . \mathrm{CH}_{2} \mathrm{CO}_{2}\right) .2 .28$ (3H. d. $J=1.7 . \mathrm{CH}_{3}$-ar). $1.92\left(2 \mathrm{H}\right.$, qn. $\left.J=7.3 . \mathrm{NHCH}_{2} \mathrm{CH}_{2}\right)$.

Hapten 2 was synthesized by the same procedure as that for Hapten 1 using 1 and 4-aminobutyric acid. Yield $73 \%$. ${ }^{1} \mathrm{H} \mathrm{NMR}\left(\mathrm{CDCl}_{3}\right): \delta 7.15$ (2H. s. ar), 3.91 (3H. d. $J=14.3$. $\mathrm{CH}_{3} \mathrm{OP}$ ). 3.47 (1H. qn. $J=7.2$. NH). 3.16 (2H. d x q. $J 6.6$ $\& 11 . \mathrm{NHCH}=2.75\left(2 \mathrm{H}\right.$. t. $\left.J=7.2 . \mathrm{CH}_{2} \mathrm{CO}_{2}\right) .2 .35(3 \mathrm{H} . \mathrm{s}$. $\mathrm{CH}_{3}$-ar), $1.99\left(2 \mathrm{H}, \mathrm{d} \times \mathrm{qn} . J=6.7 \& 1.8, \mathrm{NHCH}_{2} \mathrm{CH}_{2}\right)$.

Preparation of hapten-protein conjugates. Hapten 1 was covalently attached to BSA to use as the immunogen. Hapten 2 was conjugated to OVA to use as a coating antigen and also conjugated to HRP to use as an ellzy me tracer. The method of conjugation used was the active ester method. The procedure for the sy nthesis of the active ester of Hapten $\mathrm{l}$ is described below: The procedure for the synthesis of the other active ester was similar. Hapten 1 ( $100 \mathrm{mg} .0 .2+\mathrm{mmnol}$ ) was dissolved in $\mathrm{CH}_{2} \mathrm{Cl}_{2}(0.2 \mathrm{~mL})$ to which $\mathrm{N}$-hydroxysuccinimide (30 mg. $0.26 \mathrm{mmnol}$ ) dissolved in $5 \mathrm{~mL}$ of $\mathrm{CH}_{2} \mathrm{Cl}_{2}$ followed by $\mathrm{X}, \mathrm{X}$-dicyclohexy lcarbodiimide $(68 \mathrm{mg}$. $0.26 \mathrm{mmnol}$ ) dissolved in $0.4 \mathrm{~mL}$ of $\mathrm{CH}_{2} \mathrm{Cl}_{2}$ and 4-dimethy aminopy ridine $(3 \mathrm{mg}$ ) were added. After stirring for $1 \mathrm{~h}$, the mixture was filtered and the solvent was removed. Preparative TLC of the resultant oil on silica gel using $29: 9: 1$ $\mathrm{CHCl}_{5}$-ethyl acetate-acetic acid gave the active ester as a syrup $\left(95 \mathrm{mg} .76 \%\right.$ ). ${ }^{1} \mathrm{H}$ NMR $\left(\mathrm{CDCl}_{3}\right): \delta 7.13$ (2H. s. ar). $3.87\left(3 \mathrm{H} . \mathrm{d} . J=13.8 . \mathrm{CH}_{3} \mathrm{OP}\right) .3 .18\left(2 \mathrm{H} . \mathrm{ml} . J=4.97 . \mathrm{NCH}_{2}\right)$. $2.9 \mathrm{l}\left(3 \mathrm{H} . \mathrm{d} . J=11.2 . \mathrm{CH}_{3} \mathrm{~N}\right), 2.76(+\mathrm{H}$. s. succinyl $) .2 .43$ $\left(2 \mathrm{H} . \mathrm{sx}, J=7.35 . \mathrm{CH}_{2} \mathrm{CO}_{2}\right), 2.29\left(3 \mathrm{H} . \mathrm{d}, J=1.67 . \mathrm{CH}_{3}\right.$-ar $)$. $1.92\left(2 \mathrm{H}\right.$, qn. $\left.J=7.2 . \mathrm{NHCH}_{2} \mathrm{CH}_{2}\right)$.

The yield of active ester of Hapten 2 was $88 \%$. 'H NMR $\left(\mathrm{CDCl}_{3}\right): \delta 7.15\left(2 \mathrm{H}, \mathrm{s}\right.$. ar). $3.92\left(3 \mathrm{H}, \mathrm{d} . J=14.2 . \mathrm{CH}_{3} \mathrm{OP}\right)$. $3.28\left(2 \mathrm{H} . \mathrm{sx} . J=6.4, \mathrm{NHCH}_{2}\right) .2 .85(+\mathrm{H}$. s. succinyl). 2.49 $\left(2 \mathrm{H} . \mathrm{t} . J=7.3, \mathrm{CH}_{2} \mathrm{CO}_{2}\right) .2 .29\left(3 \mathrm{H} . \mathrm{s}, \mathrm{CH}_{3}-\mathrm{ar}\right) .2 .03(2 \mathrm{H} . \mathrm{qn}$. $J=7.0 . \mathrm{NHCH}_{2} \mathrm{CH}_{2}$ ).

The procedure for the conjugation was as follows. To prepare BSA conjugate (immunogen). BSA (20 mg. 0.3 fmol) was dissolved in $2 \mathrm{~mL}$ of borate buffer $(0.2 \mathrm{M}$. pH 8.7) to which $0.4 \mathrm{~mL}$ of DMF was added. A solution of an active ester ( $16 \mathrm{mg} .0 .03 \mathrm{mmol}$ ) dissolved in $0.1 \mathrm{~mL}$ of DMF was then added to the stirred protein solution and stirring was continued for $1 \mathrm{~h}$ at room temperature and then at $4{ }^{\circ} \mathrm{C}$ overnight. OVA conjugate (coating antigen) was prepared by the same procedure. Conjugates were purified by gel filtration (Sephadex G-25) using PBS (10 mM phosphate buffer. 137 $\mathrm{mM} \mathrm{NaCl} .2 .7 \mathrm{mM} \mathrm{KCl}, \mathrm{pH} 7.4$ ) followed by dialysis in water at + " $\mathrm{C}$ overnight. Purified conjugate solutions were then freeze-dried. HRP conjugates (enzyme tracers) were prepared similarly using the hapten-HRP molar ratios of $1 / 10$ and $1 / 50$. The conjugates were separated from uncoupled haptens by dialysis in water at $4^{\circ} \mathrm{C}$ for two days. 
Immunization of rabbits. Female New Zealand white rabbits were immunized with Hapten l-BSA. Routinely, 500 $\mu \mathrm{g}$ of the conjugate dissolved in PBS emulsified with Freund's complete adjuxant ( $1: 1$ volume ratio) was injected intradermally at multiple sites on the back of each rabbit. After two weeks. each animal was boosted with an additional $500 \mu \mathrm{g}$ of the conjugate emulsified with Freund's incomplete adjuxant and bled 7-10 days later. After this. boosting and bleeding was continued on a montly basis. Serum was isolated by centrifugation. and sodium azide was added as a preservative at a final concentration of $0.02 \%$. Serum was then aliquoted and stored at $-70^{\circ} \mathrm{C}$.

Screening of antisera. Checkerboard assays, in which sera were titrated against varying amounts of the coating antigen were used to measure reactivity of antibodies and to select appropriate antigen coating and antibody dilutions for competitive indirect assays. The assay procedure was as follows. Microtiter plates were coated with Hapten 2-OVA (200-1000 ng/mL. 100 $\mu \mathrm{L} /$ well) in Tris buffer $(50 \mathrm{mM}, \mathrm{pH}$ 7.8) by overnight incubation at $+{ }^{\circ} \mathrm{C}$. The plates were washed five times with PBST (PBS containing 0.05\% Tween 20. pH 7.4) and were blocked by incubation with $1 \%$ gelatin in PBS (200 $\mu \mathrm{L} /$ well) at room temperature for $1 \mathrm{~h}$. After another washing step. $100 \mu \mathrm{L} / \mathrm{w}$ ell of antiserum previously diluted with PBST (1/1000-1/2000) was added. After incubation at room temperature for $1 \mathrm{~h}$. the plates were washed and 100 $\mu \mathrm{L} /$ well of a diluted ( $1 / 2000$ or $1 / 3000)$ goat anti-rabbit lgGHRP was added. The mixture was incubated at room temperature for $1 \mathrm{~h}$, and after another washing step, $100 \mu \mathrm{L} /$ well of a TMB solution $(400 \mu \mathrm{L}$ of $0.6 \%$ TMB-DMSO and $100 \mu \mathrm{L}$ of $1 \% \mathrm{H}_{2} \mathrm{O}_{2}$ diluted with $25 \mathrm{~mL}$ of citrate-acetate buffer. $\mathrm{pH}$ 5.5) was added and incubated at room temperature. The reaction was stopped after an appropriate time (10-20 min) by adding $50 \mu \mathrm{L}$ of $2 \mathrm{M} \mathrm{H}_{2} \mathrm{SO}$, and absorbance was read at $450 \mathrm{~nm}$.

Competitive indirect ELISA. To develop an antigencoated (indirect) ELISA, antigen coating and antibody concentration for competitive assays were optimized again. Also the tolerance of ELISA to various concentrations of methanol used to dissolve the nonpolar pesticide was tested for assay optimization. For this test. standard solutions were prepared by dissolving the analyte in a mixture of $10 \mathrm{mM}$ PBS and methanol in various proportions (10.20 and $40 \%$ methanol. which became 5, 10 and $20 \%$ after combining with equal volume of a diluted antiserum) by serial dilutions from a stock solution. The effect of phosphate ion concentration on ELISA performance was studied using different concentrations of PBST used to dissolve the antisera (10.90. 190 and $390 \mathrm{mM}$ phosphate which became 10,50 . 100 and $200 \mathrm{mM}$. respectively; after combining with equal volume of pesticide standard in $10 \mathrm{mM}$ PBS). The procedure of the competitive assay was as follows. To microtiter plates coated and blocked as described above. $50 \mu \mathrm{L} /$ well of serial dilutions of the analyte in methanol-PBS was added. followed by 50 $\mu \mathrm{L} /$ well of a previously determined antisenum dilution. After incubation at room temperature for $l \mathrm{~h}$. antibody binding was assessed as described above. Competition curves were obtained by plotting absorbance against the logaritlum of analyte concentration. Sigmoidal curves were fitted to a four-parameter logistic equation. ${ }^{15}$ from which $\mathrm{IC}_{51,}$, values (concentration at which binding of the antibody to the coating antigen is inhibited by $50 \%$ ) are deternined.

Competitive direct assay. A checkerboard assay, in which sera were titrated against varying amounts of the enzyme tracer (Hapten 2 conjugated to HRP) was used to optimize the amount of enzyme tracer and antibody: The procedure was the same as that for competitive assays (see below) except that only solvent instead of pesticide solution was added at the competition step. The competitive antibodycoated assays under the optimized conditions were performed as follows. Microtiter plates were precoated with protein $\mathrm{A}$ (5 $\mu \mathrm{g} / \mathrm{mL}$. $100 \mu \mathrm{L} /$ well) in carbonate-bicarbonate buffer $(50$ $\mathrm{mM}, \mathrm{pH} 9.6)$ by overnight incubation at $4{ }^{\circ} \mathrm{C}$. The plates were washed five times with PBST and were coated with $100 \mu \mathrm{L}$ of the antiserum dilutions (1/2000) in PBST for $l \mathrm{~h}$ at room temperature. After another washing step, serial dilutions of the analyte in $20 \% \mathrm{MeOH}-\mathrm{PBS}$ were added $(50$ $\mu \mathrm{L} /$ well) followed by $50 \mu \mathrm{L} /$ well of the enzyme tracer previously diluted with PBS. After incubation at room temperature for $\mathrm{I} h$ and another washing step. $100 \mu \mathrm{L} /$ well of a TMB solution was added. The reaction was stopped after an appropriate time by adding $50 \mu \mathrm{L}$ of $2 \mathrm{M} \mathrm{H}_{2} \mathrm{SO}_{1}$ and absorbance was read at $450 \mathrm{~lm}$. Competition curves were obtained by the same procedure as that used for the indirect assays.

Determination of cross-reactivities. The compounds listed in Table 3 were tested for cross-reactivity by preparing standard curves using the indirect assays and determining their $\mathrm{IC}_{2}$ values (concentration at which binding of the antibody to the coating antigen is inhibited by $20 \%$ ). The cross-reactivity values were calculated as follows: (IC $\mathrm{I}_{2,}$ of tolclofos-methy $\mathrm{V} / 1 \mathrm{C}_{21}$ of compound) $\times 100$.

\section{Results and Discussion}

Hapten design and synthesis. The majority of OP pesticides have the thiophosphate group in common and differ only in the structure of aromatic rings. Therefore. to achieve a high selectivity in tolclofos-methyl ELISA. it was desirable to synthesize immunizing haptens having a bridge at the thiophosphate group preserving the aromatic ring unique to tolclofos-methyl. Hapten 1 was chosen as a immunizing hapten on this ground. Heldman el $a l^{2}$ were the first to synthesize a hapten for OP pesticide with a spacer arm at the thiophosphate group. However. a general method was developed later by Skerritt et al. 16.1? This method was applied to the synthesis of haptens for the development of ELISAs of several OP pesticides. ${ }^{-1}$ ? This method requires a synthetic route involving seven steps including protection and deprotection of both amino and carboxyl groups. In an effort to simplify the synthetic process for this class of haptens. we developed a simpler general method. which requires only two steps. ${ }^{+-6}$ It involves the reaction of ()methyl (ethyl) dichlorothiophosphate with a phenol and 
Table 1. Liliects of methanol concentration on assay parameters of indired LLISA"

\begin{tabular}{|c|c|c|c|}
\hline $\begin{array}{c}\text { Methauso] } \\
\left({ }^{\circ} 0\right)^{b}\end{array}$ & $A b s_{\text {max }}$ & Slope & $\begin{array}{c}\mathrm{IC}_{q_{01}} \\
(\mu \mathrm{g}: \mathrm{ml} .)\end{array}$ \\
\hline 5 & 1.035 & 0.852 & 0.345 \\
\hline 10) & ].1] & 0.978 & 01.2014 \\
\hline 20 & 1.270 & 0.911 & 11.267 \\
\hline
\end{tabular}

"ELISA conditions: antiserum to Hapten l-BSA. diluted 12000 with 10 mM PBS l: coating antigen. Hapten 2-OVA. 15 ng well: goat anti-rabbil IgG-IIRP diluted I.3000. Data were obtained from the four-parameter sigmoidal titting. Fach set of data represents the average of three replicates. "Final concentration in the competition solution.

Table 2. Lificts of bullew concentration on assay paramaters of indireet LLLSA"

\begin{tabular}{|c|c|c|c|c|}
\hline $\begin{array}{c}\text { Concentration } \\
(\mathrm{mM})^{b}\end{array}$ & $\begin{array}{l}\text { lneubation } \\
\text { lime (min) }\end{array}$ & $A b S_{\text {mIntax }}$ & Slope & $\begin{array}{c}\mathrm{IC} \cdot \mathrm{c}_{00} \\
(\mu \mathrm{gl})(\mathrm{ml})\end{array}$ \\
\hline 10 & 12 & 1.593 & 0.804 & 1.241 \\
\hline 50 & 18 & 1.302 & 0.838 & 0.385 \\
\hline 100 & 25 & 1.018 & 0.767 & 0.236 \\
\hline 200 & 30 & 0.646 & 0.602 & 0.284 \\
\hline
\end{tabular}

"TIISA conditions were the same as those described in Table 1. Data were oblained from the four-parameter sigmoidal fitting. Eacla sel of dala represents the average of three replicales. "Final concentration ol phosphate butfer of the competition solution. 'Time for color derclopment

$\mathrm{K}_{-} \mathrm{CO}_{3}$ in acetonitrile and the reaction of the substitution product with an aminocarboxylic acid (not protected) and $\mathrm{KOH}$ in $\mathrm{MeOH}$ (see Figure 2 for an example). This method was successfully applied to the synthesis of the two haptens for tolclofos-methyl. It worked well for attaching a secondary (Hapten 1) as well as a primary aminocarbosylic acid (Hapten 2). The reactions proceeded facilely with relatively high yield: $67 \%$ in the first. and over $70 \%$ in the second reaction, respectively. The reaction time was relatively short: $1 \mathrm{~h}$ and a few mimutes for the first and second reaction. respectively: This method was successfully applied in this laboratory to the synthesis of haptens of several other OP pesticides such as chlorpy rifos. ${ }^{4}$ isofenphos and cyanophos. ${ }^{6}$ and we applied for a patent. All the carboxylic acid haptens could be coiverted to the succinimide esters. active esters for coupling haptens to carrier proteins.

Indirect ELISA. Of the four antisera obtained. the one that exhibited the most inhibition by the analyte was selected as the assay reagent. In addition to optimizing antigen coating (15 ng/well) and antiserum dilution $(1 / 2000)$. the concentrations of methanol and buffer in the competition step media were optimized. Since organic solvents are commonly used in the sample preparation for nonpolar pesticides. it is desirable to assess the effects of organic cosolvents on ELISA characteristics. Since several workers reached the same conclusion that methanol causes the least negative effect of the solvents tested. ${ }^{(8-y)}$ methanol was chosen as a cosolvent. Table 1 shows the effect of methanol concentration on ELISA performance. Increasing the concentration of methanol of the standard solutions affected the sensitivity of the assay to a small extent. The optimum

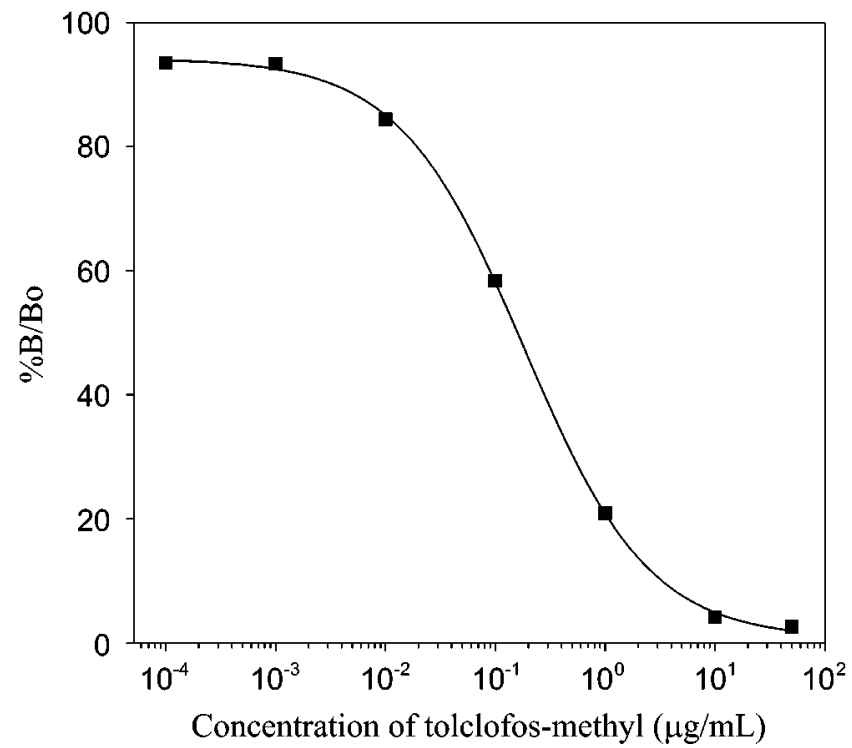

Figure 3. Standard curve for tolclofos-methyl by competitive indirect FI,ISA using the antisenum against Hapten I-BSA diluted 1/2000, the coating antigen I laplen 2-OVA ( $15 \mathrm{ng} / \mathrm{hell}$ ) and gelatin blocking agent $(1 \%)$. The composition of the assat solution was $10 \%$ methanol-PBS $(100 \mathrm{mM})$

concentration of methanol in the standard solution was determined to be $20 \%$ ( $10 \%$ after combining with equal volume of antiserum). where ${ } \mathrm{C}_{5 !, 1}$ was lowest. Table 2 presents the effect of the phosphate ion concentration at the competition step on ELISA characteristics. Increasing the concentration of the phosphate caused a large increase of sensitivity up to $100 \mathrm{mM}$ phosphate followed by a decrease of sensitivity: Since increased buffer concentration causes a remarkable retardation of the color development. selecting optimum buffer concentration would depend on the sensitivity as well as speed of color development in assay: The optimum concentration chosen was $100 \mathrm{mM}$. where $\left[\mathrm{C}_{5,1}\right.$

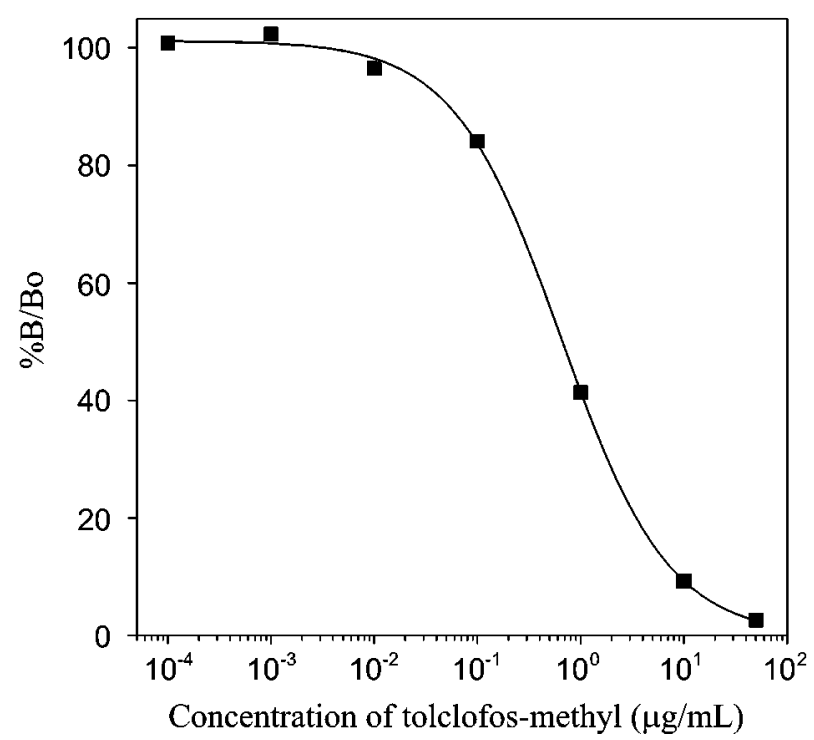

Figure 4. Standard curve for tolclotos-methy l by competitive direct FIISA using the antiserum against Hapten 1-BSA diluted 1/1000. the enyme tracer Hapten 2-I LRP and gelatin blocking agent (1\%). 
Table 3. Cross-reactivit profiles ol the antibodiess

Pesticide

"Determined bx indirect ELISA under the condition described in lable l. "IC $C_{20}$ values of the pesticides belon parathion-methyl conld not be detemined accurately due to the limited solubility at high concentrations, howerer, it was elear that inhibition was less than $20^{\circ}$ o at 100 ppm. "Cross-reactivity $\left({ }^{\circ} 0\right)-\left(\mathrm{IC}_{211}\right.$ of tolclofos-methyl ${ }_{20}$ of other compound) $\times 100$.

value was lowest and the speed of color development was not critically slow: Figure 3 shows a typical inhibition curve obtained after optimization. The lowest $\mathrm{IC}_{\bar{S} \mathrm{i}}$ value obsened was $160 \mathrm{ng} / \mathrm{mL}$ with a detection limit of about $20 \mathrm{ng} / \mathrm{mL}$ (20\% inluibition).

Direct ELISA. The enzyme tracer for direct ELISA was prepared by conjugation reaction of Hapten 2 with HRP at $1: 10$ or $1: 50$ molar ratio. Hapten 2-HRP prepared at $1: 10$ molar ratio gave better results than the other one. The antibody-coated ELISA using this enzy me tracer was optimized with regard to the dilution of antisenum and enzy me tracer. Figure 4 shows the inhibition curve obtained after optimi-

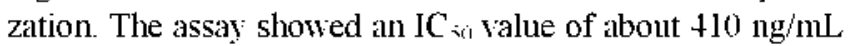
with a detection limit of about $130 \mathrm{ng} / \mathrm{mL}$. The sensitivity of this ELISA is considerably lower than that of the ELISA previously developed ( $\mathrm{IC}_{30}$ value of $2 \mathrm{ng} / \mathrm{mL}$ ). Since the structures of the enzyme tracers and assay procedures were similar the sensitivity difference nust have resulted from the difference in antibody characteristics. Since this assay showed a sensitivity inferior to that of the indirect ELISA. no further optimization was attempted.

Cross-reactivity of the assays. Several OP pesticides as well as tolclofos-metlyyl metabolites were tested for crossreactivities. Table 3 shows the cross-reactivity that was found by the indirect assay. expressed in percentage of the IC $C_{2}$ of tolclofos-methyl. In all cases. the interference to the assay was negligible. It may be concluded that the indirect ELISA that was developed is suitable for the selective detection of tolclofos-methyl.

Acknowledgment. This work was supported by a Korea Research Foundation Grant (KRF-2001-005-D-20014).

\section{References}

1. The Pesticide Mamal af Hontd Compendium. I the ed.: 'Tomlin. C. D. S. Ed.: The British Crop P'rotection Council: Famlam. Surrey. U.K.. 1997: p 238 .

2. Official Wethods of lnalssis, 18th $\mathrm{\Gamma d}$.: NOAC Intemational: Arlington. VA, 1995: Section 970.52 .

3. I Jammock, B. D.: Gee, S. I.: I Iarrisotn. R. O.: Jung. F.: Gondrow; M. H.: Li. Q. X.: Lucas. A.: Szekacs. A.: Sundaram. K. M. S. Immenochemical Wethods for Emiromental Andhisis. Van Emon. J.. Mumma. R.. Eds.: ACS Symposium Series 442: Americun Chemical Socicty: Washington. DC, USA, 1990: pp 112-1.39

4. Cho, Y. A.: J.ce, II.S.: Park, F. Y.: I.ce, Y. T.: Hammock. B. D.: Ahn, K. C.: J.ce. J. K. Bull Korean Chem. Soc. 2002. 23, 481-487.

5. I'ark. H. J.: l'ark. W. C.: Jung. T. W.: Rha. C. S.: Lee. Y. 'I. Bu/l. Sorem Chem. Soc. 2002. 23. $599-604$.

6. P'urk. I. H.: P'urk. W. C.: Kim. Y. I.: Lee. Y. 'T. Bull. Konew Chem. Soc. 2002. 23. 605-609.

7. IIeldman, F... Balan, A.: IIorowitz. O.: Ben-7ion. S.: Torten. M. FIERS Lett. 1985, 180. 24.3-248.

8. McAdam. D. 1:: Hill. A. S.: Beasley. H. L.: Skerritt. J. H. J. tgric. Food $C \%$ w. 1992. $40.1466-1470$.

9. Manclus. J. J.: P'rimo. J.: Montoya. A. J. tgric. Food Chem. 1996. 4H. $4052-4062$.

10. IIill, A. S.: Sherritt, I. H.: Bushway, R. I.: Pertins. I.. B.: I.arkin. K.: Thomas. M: Korth, W: Bowmer. K. II. J Igric. Fond ( $h h^{\prime}$ in. 1994. +2. 2051-2058.

11. Edward. S. L.: Skerritt. J. H.: Hill. A. S.: McAdam. D. P. Food Agric. Immonot. 1993. 5. 129-144.

12. Sheritt, J. II.: H Iill, A. S.: Thwaites, II. I..; Fdward. S. I..: MeAdam, D. P. . . 1O.K Itt. 1992, 75. 519-528.

1.3. Kawada, M.: Morimume. K.: Kanai, S.: Kagana, Y.: Watanabc. K. Jopim P'atemt 11-255786. 1999.

14. Tabor. E. J. Lnife States P'atent 3,005,005. 1961

15. Raab. G. M. Chin. Chem. 1983. 29. 1757-1761.

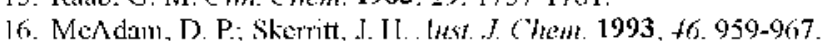

17. Skerritt, I. I1.: I.ee, N. I. Residhe . Inalysis in Food Saffety: . Applications of Immmoassay Wethods: Beicr. R. C., Stanker. I. H.. Eds.: ACS Symposium Series 621: American Chemical Society: Washington DC. USA. 1996: pp 124-149.

18. Marco. M.-1:. Gee. S. J.: Cheng. H. M.: Liang. L. Y.: Hammock. B. D. J. Lgric. Food $\left(\mathrm{hh}^{\prime} \mathrm{m} . \mathbf{1 9 9 3}, \mathrm{H}, 42.3-4.30\right.$.

19. Wengat7, I.: Stoutamirc. D. W.: Gec. S. I.: Uammock. B. D. J. igric Fod Chem 1998, 46.2211-2221.

20. Shan. G.: Leeman. W. R.: Stoutamire. D. W.: Gee. S. I.: Chang. D. P. Y.: Hammock. B. D. J. Agric. Foesd Chem. 2000. $18.4032-4040$. 